\title{
Niastella populi sp. nov., isolated from soil of Euphrates poplar (Populus euphratica) forest, and emended description of the genus Niastella
}

\author{
Correspondence \\ Chengxiang Fang \\ cxfang@whu.edu.cn
}

\author{
Kundi Zhang, ${ }^{1}$ Yang Wang, ${ }^{1}$ Yali Tang, ${ }^{1}$ Jun Dai, ${ }^{1}$ Lei Zhang, ${ }^{1}$ Hongli An, ${ }^{1}$ \\ Guangchao Luo, ${ }^{1}$ Erkin Rahman ${ }^{2}$ and Chengxiang Fang ${ }^{1}$ \\ ${ }^{1}$ College of Life Sciences, Wuhan University, Wuhan 430072, PR China
${ }^{2}$ College of Life Science and Technology, Xinjiang University, Urumchi 830046, PR China
}

The genus Niastella, containing Niastella koreensis (type species) and Niastella yeongjuensis, was proposed by Weon et al. (2006) for bacterial strains isolated from soil cultivated with Korean ginseng. These organisms are Gram-staining-negative, aerobic, filamentous bacteria that are motile by gliding, that do not produce flexirubin pigments and do not reduce nitrate. Their cellular fatty acids include large amounts of iso- $\mathrm{C}_{15: 0}$, iso- $\mathrm{C}_{15: 1} \mathrm{G}$ and iso- $\mathrm{C}_{17: 0} 3-\mathrm{OH}$ and their major respiratory quinone is MK-7. Phylogenetically, the genus Niastella is a member of the family Chitinophagaceae, phylum Bacteroidetes (http:// www.bacterio.net).

In the present study, a novel member of the genus Niastella was characterized. Strain THYL- $44^{\mathrm{T}}$ was isolated from the soil of a Euphrates poplar (Populus euphratica) forest $\left(84^{\circ} 15^{\prime} \sim 84^{\circ} 30^{\prime} \mathrm{E}, 40^{\circ} 0^{\prime} \sim 40^{\circ} 55^{\prime} \mathrm{N}\right)$ in Xinjiang, China. The soil sample was diluted with sterile water and the dilutions were plated onto $0.1 \times$ TSA (tryptic soy agar; Difco) plates. The strain was isolated after incubation at $30{ }^{\circ} \mathrm{C}$ for one week. However, it was later noticed that the isolate grew better on R2A agar (Difco).

The GenBank/EMBL/DDBJ accession number for the $16 \mathrm{~S}$ rRNA gene sequence of strain THYL- $44^{\top}$ is EU877262.

A maximum-parsimony phylogenetic tree and a transmission electron micrograph of cells of strain $\mathrm{THYL}-44^{\top}$ are available as supplementary figures in the online version of this paper.
Cell morphology was examined by phase-contrast microscopy (BX51; Olympus) and transmission electron microscopy (8100; Hitachi), using cells negatively stained with $2 \%(\mathrm{w} / \mathrm{v})$ phosphotungstic acid after air drying. Gram staining was carried out according to the classical Gram procedure described by Doetsch (1981). Motility was examined according to the method of Bernardet et al. (2002). Growth at $4,17,22,25,30,37,42$ and $50{ }^{\circ} \mathrm{C}$ and at $\mathrm{pH} 5.0-10.0$ (at $1.0 \mathrm{pH}$ unit intervals) was tested after 5 days of incubation in $\mathrm{R} 2 \mathrm{~A}$ broth. The $\mathrm{pH}$ was adjusted using $1 \mathrm{M} \mathrm{HCl}$ or $1 \mathrm{M} \mathrm{NaOH}$ and the broth was then filter-sterilized at $0.2 \mu \mathrm{m}$. Salt tolerance was tested on R2A agar supplemented with $0-10 \%(\mathrm{w} / \mathrm{v}) \mathrm{NaCl}$ (at $1 \%$ intervals). Catalase activity was determined by assessing bubble production in $3 \%(\mathrm{v} / \mathrm{v}) \mathrm{H}_{2} \mathrm{O}_{2}$ and oxidase activity was determined using $1 \%(\mathrm{w} / \mathrm{v})$ tetramethyl-p-phenylenediamine. Growth under anaerobic conditions was tested on $\mathrm{R} 2 \mathrm{~A}$ agar in a GasPak (BBL) jar at $30{ }^{\circ} \mathrm{C}$ for 10 days. The following tests were performed on strain THYL- $44^{\mathrm{T}}$ and on the type strains of the recognized species of the genus Niastella. Hydrolysis of carboxymethylcellulose, casein, chitin, DNA, agar, tyrosine and starch was performed using the methods of Smibert \& Krieg (1994). Flexirubin pigments were detected by means of a colour shift after exposure to a $20 \%(\mathrm{w} / \mathrm{v}) \mathrm{KOH}$ solution (Reichenbach, 1992). Congo red absorption was tested by directly flooding colonies on agar plates with $0.01 \%$ aqueous 
Congo red solution. Other biochemical tests were carried out by using API 20NE, API ID 32GN and API ZYM test kits according to the manufacturer's instructions (bioMérieux). Growth was also evaluated on nutrient agar (NA; Difco), TSA (Difco) and MacConkey agar (Difco) at $30{ }^{\circ} \mathrm{C}$.

Genomic DNA was extracted with a Bacteria Genomic DNA isolation kit (Shanghai Chaoshi Bio Technologies Co. Ltd). The 16S rRNA gene was amplified by PCR with bacterial universal primers 27F and 1527R (Rainey et al., 1996) and the PCR products were sequenced by Invitrogen Biotechnology Co. Ltd. Sequence similarity was calculated by pairwise alignment obtained from the EzTaxon database (Chun et al., 2007). Analysis of the 16S rRNA gene sequence data was performed by using the MEGA version 4.0 software package (Tamura et al., 2007), after multiple alignment of the data by CLUSTAL_X (Thompson et al., 1997). A distance matrix method (distance options according to the Kimura two-parameter model) using clustering with the neighbourjoining (Saitou \& Nei, 1987) method (Fig. 1) as well as a discrete character-based maximum-parsimony (Fitch, 1971) method (see Supplementary Fig. S1 available in IJSEM Online) were used. In each case, bootstrap values were calculated based on 1000 replications (Felsenstein, 1985). The 16S rRNA gene sequence of strain THYL- $44^{\mathrm{T}}$ was a continuous stretch of $1445 \mathrm{bp}$. Sequence similarity calculations indicated that strain THYL- $44^{\mathrm{T}}$ showed the highest degree of similarity to Niastella koreensis KACC $11465^{\mathrm{T}}$ $(95.5 \%)$ and N. yeongjuensis KACC $11466^{\mathrm{T}}$ (95.4\%). Lower sequence similarities $(<93.6 \%)$ were found with all other organisms in Fig. 1. The 16S rRNA gene sequence of strain THYL $-44^{\mathrm{T}}$ is therefore distinctly different from those of members of the family Chitinophagaceae (Stackebrandt \& Goebel, 1994).

To determine the whole-cell fatty acid profiles, strain THYL$44^{\mathrm{T}}, N$. koreensis DSM $17620^{\mathrm{T}}$ and N. yeongjuensis DSM $17621^{\mathrm{T}}$ were cultured on R2A agar at $30{ }^{\circ} \mathrm{C}$ for 3 days. Fatty acid methyl esters were obtained by saponification, methylation and extraction as described previously (Kämpfer \& Kroppenstedt, 1996) and separated by GC (6890; Agilent). Peaks were integrated automatically and fatty acid names and percentages were determined using the Sherlock Microbial Identification System (MIDI). The fatty acid profile of strain THYL- $44^{\mathrm{T}}$ revealed iso- $\mathrm{C}_{15: 0}(28.6 \%)$, iso- $\mathrm{C}_{17: 0} 3-\mathrm{OH}(23.9 \%)$ and iso- $\mathrm{C}_{15: 1} \mathrm{G}(17.4 \%)$ as the major fatty acids. This composition was essentially in agreement with the fatty acid patterns of species of the genus Niastella obtained using different (Weon et al., 2006) and identical (this study; Table 1) growth conditions. Segetibacter koreensis KCTC $12655^{\mathrm{T}}$ showed large amounts of fatty acid $\mathrm{C}_{16: 1} \omega 5 c$ (An et al., 2007) and thus could be clearly differentiated from $N$. koreensis DSM $17620^{\mathrm{T}}, N$. yeongjuensis DSM $17621^{\mathrm{T}}$ and strain THYL- $44^{\mathrm{T}}$.

Biomass for molecular systematic and chemotaxonomic studies was obtained from R2A broth cultures in shaken flasks at $30{ }^{\circ} \mathrm{C}$ for 3 days. The genomic DNA of strain THYL- $44^{\mathrm{T}}$ was prepared according to a modification of the procedure of Wilson (1987). The determination of the DNA $\mathrm{G}+\mathrm{C}$ content was performed according to the method of Mesbah et al. (1989) using reversed-phase HPLC (UltiMate 3000; Dionex). The DNA G + C content of strain THYL $-44^{\mathrm{T}}$ was $45.2 \mathrm{~mol} \%$ which was in line with the values reported previously for species of the genus Niastella (44.3$45.8 \mathrm{~mol} \%$ ). Respiratory quinones were isolated from lyophilized cells as described by Collins et al. (1977) and were analysed by HPLC as described by Xie \& Yokota (2003). The presence of MK-7 supported the affiliation of strain THYL $-44^{\mathrm{T}}$ to the family Chitinophagaceae, in which all species investigated to date have MK-7 as the major quinone.

In terms of physiological and biochemical properties, strain THYL $-44^{\mathrm{T}}$ could be distinguished from members of the genera Terrimonas (Xie \& Yokota, 2006), Flavisolibacter and Segetibacter (Yoon \& Im, 2007) by the ability to hydrolyse casein, the absence of oxidase activity and the enzyme

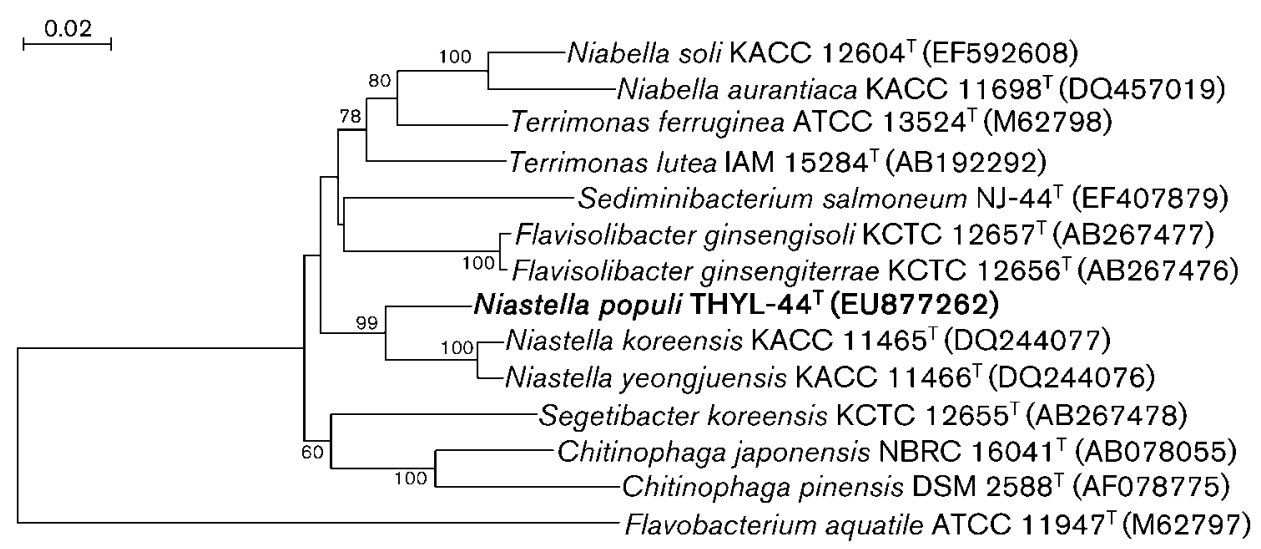

Fig. 1. Neighbour-joining phylogenetic tree based on $16 \mathrm{~S}$ rRNA gene sequences, showing the relationship of strain THYL-44 ${ }^{\top}$ and related taxa. Bootstrap values $(>50 \%)$ are shown at nodes as percentages of 1000 replicates. Flavobacterium aquatile ATCC $11947^{\top}$ was used as an outgroup. Bar, 0.02 substitutions per nucleotide position. 
Table 1. Fatty acid contents (\%) of strain THYL $-44^{\top}$ and the type strains of the recognized species of the genus Niastella

Strains: 1 , THYL- $44^{\mathrm{T}} ; 2$, N. koreensis DSM $17620^{\mathrm{T}} ; 3$, N. yeongjuensis DSM $17621^{\mathrm{T}}$. All data are from this study. - , Not detected; tr, traces $(<1 \%)$. Fatty acids amounting to $<1 \%$ of total fatty acids in all three strains are omitted. The major fatty acids are indicated in bold type.

\begin{tabular}{|c|c|c|c|}
\hline Fatty acid & 1 & 2 & 3 \\
\hline \multicolumn{4}{|l|}{ Saturated fatty acids } \\
\hline $\mathrm{C}_{16: 0}$ & 4.0 & 4.8 & 2.9 \\
\hline $\mathrm{C}_{18: 0}$ & 2.0 & 2.4 & $\operatorname{tr}$ \\
\hline \multicolumn{4}{|c|}{ Unsaturated fatty acids } \\
\hline $\mathrm{C}_{16: 1} \omega 5 c$ & - & - & 1.0 \\
\hline \multicolumn{4}{|c|}{ Branched-chain fatty acids } \\
\hline anteiso- $\mathrm{C}_{15: 0}$ & 4.9 & 4.5 & 5.5 \\
\hline iso- $\mathrm{C}_{15: 0}$ & 28.6 & 23.3 & 29.1 \\
\hline iso- $\mathrm{C}_{15: 0} 3-\mathrm{OH}$ & 1.6 & 1.3 & 2.1 \\
\hline iso- $\mathrm{C}_{15: 1} \mathrm{G}$ & 17.4 & 15.8 & 14.8 \\
\hline iso- $\mathrm{C}_{17: 0}$ & $\operatorname{tr}$ & $\operatorname{tr}$ & 1.0 \\
\hline iso- $\mathrm{C}_{17: 0} 3-\mathrm{OH}$ & 23.9 & 25.9 & 23.4 \\
\hline \multicolumn{4}{|l|}{ Hydroxy fatty acids } \\
\hline $\mathrm{C}_{16: 0} 3-\mathrm{OH}$ & 1.6 & 1.4 & 1.7 \\
\hline $\mathrm{C}_{17: 0} 2-\mathrm{OH}$ & 1.8 & 2.9 & 2.3 \\
\hline $\mathrm{C}_{17: 0} 3-\mathrm{OH}$ & $\operatorname{tr}$ & 1.5 & $\operatorname{tr}$ \\
\hline Summed feature $3^{*}$ & 6.2 & 6.8 & 5.7 \\
\hline
\end{tabular}

${ }^{*}$ Summed features are groups of two or three fatty acids that cannot be separated by GLC with the MIDI system. Summed feature 3 contained $\mathrm{C}_{16: 1} \omega 5 \mathrm{c}$ and/or iso- $\mathrm{C}_{15: 0} 2-\mathrm{OH}$.

reaction pattern in the API ZYM test kit. Furthermore, strain THYL- $44^{\mathrm{T}}$ could be differentiated from the two recognized members of the genus Niastella on the basis of its ability to assimilate a number of carbohydrates, inability to hydrolyse chitin and absence of gliding motility. Other differentiating characteristics are shown in Table 2.

On the basis of these results, strain THYL- $44^{\mathrm{T}}$ represents a novel species of the genus Niastella, for which the name Niastella populi sp. nov. is proposed. As a consequence of newly reported characteristics, the description of the genus Niastella Weon et al. 2006 needs to be emended.

\section{Emended description of the genus Niastella Weon et al. 2006}

The main characteristics are as those given for the genus description by Weon et al. (2006). In addition, cells are motile by gliding or are non-motile. Growth on TSA and hydrolysis of chitin, carboxymethylcellulose and tyrosine are species-dependent.

\section{Description of Niastella populi sp. nov.}

Niastella populi (po'pu.li. L. gen. n. populi of a poplar, pertaining to Populus, the Latin name of the poplars that grow in the forest from which the strain was isolated).
Table 2. Phenotypic characteristics that differentiate strain THYL $-44^{\top}$ from the type strains of the recognized species of the genus Niastella

Strains: 1 , THYL- $44^{\mathrm{T}} ; 2$, Niastella koreensis DSM $17620^{\mathrm{T}} ; 3$, Niastella yeongjuensis DSM $17621^{\mathrm{T}}$. All data are from this study except the DNA G + C contents of taxa 2 and 3 (Weon et al., 2006). +, Positive; - , negative.

\begin{tabular}{|lccc|}
\hline Characteristic & $\mathbf{1}$ & $\mathbf{2}$ & $\mathbf{3}$ \\
\hline Oxidase activity & - & - & + \\
Gliding motility & - & + & + \\
Colony colour & Yellow & Light yellow & Milky \\
Hydrolysis of chitin & - & + & + \\
Enzyme activities (API ZYM): & & & \\
$\alpha$-Chymotrypsin & - & - & + \\
$\alpha$-Glucosidase & + & + & $+^{*}$ \\
$\beta$-Glucosidase & + & + & $+^{*}$ \\
Assimilation of (API 20NE and API ID & $32 \mathrm{GN})$ : & & \\
$\quad$ N-Acetyl- $\beta$-glucosamine & + & - & - \\
L-Arabinose & + & - & - \\
D-Glucose & + & - & - \\
L-Histidine & + & - & - \\
Maltose & + & - & - \\
D-Mannose & + & - & - \\
Melibiose & + & - & - \\
L-Rhamnose & + & - & - \\
Salicin & + & - & - \\
L-Serine & + & - & - \\
Sucrose & + & - & - \\
DNA G+C content $($ mol\%) & 45.2 & 45.8 & 44.3 \\
& & & \\
\hline
\end{tabular}

${ }^{\star}$ Weak positive reaction according to Weon et al. (2006).

Cells are strictly aerobic, Gram-staining-negative, filamentous rods approximately $0.2-0.5 \mu \mathrm{m}$ wide and $6-30 \mu \mathrm{m}$ long (see Supplementary Fig. S2 available in IJSEM Online) and are devoid of flagella and exhibit no gliding motility. Colonies on R2A agar are rough, convex, irregular and yellow-coloured. Growth occurs at $17-37^{\circ} \mathrm{C}$, at $\mathrm{pH} 5.0-8.0$ and in the presence of $0-1 \% \mathrm{NaCl}(\mathrm{w} / \mathrm{v})$; growth is optimal at $30{ }^{\circ} \mathrm{C}$, at $\mathrm{pH} 7.0$ and in the absence of $\mathrm{NaCl}$. Grows on R2A, NA and TSA, but not on MacConkey agar. Oxidaseand catalase-negative. Flexirubin pigments are not produced and Congo red is not absorbed. Casein is hydrolysed. Chitin, carboxymethylcellulose, starch, tyrosine, agar and DNA are not hydrolysed. In API 20NE and API ID 32GN strips, D-glucose, L-arabinose, D-mannose, Lrhamnose, $N$-acetyl- $\beta$-glucosamine, L-serine, salicin, melibiose, maltose, sucrose and L-histidine are assimilated. DMannitol, potassium glucosamine, capric acid, adipic acid, malic acid, trisodium citrate, phenylacetic acid, D-ribose, inositol, itaconic acid, suberic acid, sodium malonate, sodium acetate, lactic acid, L-alanine, potassium 5ketogluconate, glycogen, 3-hydroxybenzoic acid, L-fucose, D-sorbitol, propionic acid, capric acid, valeric acid, trisodium citrate, potassium 2-ketogluconate, 3-hydroxy- 
butyric acid, 4-hydroxybenzoic acid and L-proline are not assimilated. In API 20NE and API ZYM strips, reactions are positive for aesculin and gelatin hydrolysis and for alkaline phosphatase, leucine arylamidase, valine arylamidase, acid phosphatase, naphthol-AS-BI-phosphohydrolase, $\beta$-galactosidase, $\alpha$-glucosidase, $\beta$-glucosidase, $N$ acetyl- $\beta$-glucosaminidase, $\alpha$-mannosidase and $\alpha$-fucosidase activities; weakly positive for esterase (C4), esterase lipase (C8), lipase (C14), cystine arylamidase and $\alpha$-galactosidase activities, and negative for nitrate reduction, indole production, glucose fermentation and arginine dihydrolase, urease, trypsin, $\alpha$-chymotrypsin and $\beta$-glucuronidase activities. The predominant isoprenoid quinone is MK-7. The major cellular fatty acids $(>17 \%)$ are iso- $C_{15: 0}$, iso$\mathrm{C}_{17: 0} 3-\mathrm{OH}$ and iso- $\mathrm{C}_{15: 1} \mathrm{G}$.

The type strain, THYL- $44^{\mathrm{T}} \quad\left(=\mathrm{CCTCC}\right.$ AB $208238^{\mathrm{T}}$ $=$ KCTC $22560^{\mathrm{T}}$ ), was isolated from the soil of a Euphrates poplar forest in Xinjiang, China. The DNA $\mathrm{G}+\mathrm{C}$ content of the type strain is $45.2 \mathrm{~mol} \%$.

\section{Acknowledgements}

This work was funded by the R \& D Infrastructure and Facility Development Program from the Ministry of Science and Technology of the People's Republic of China (Grant No. 2005DKA21208).

\section{References}

An, D. S., Lee, H. G., Im, W. T., Liu, O. M. \& Lee, S. T. (2007). Segetibacter koreensis gen. nov., sp. nov., a novel member of the phylum Bacteroidetes, isolated from the soil of a ginseng field in South Korea. Int J Syst Evol Microbiol 57, 1828-1833.

Bernardet, J.-F., Nakagawa, Y. \& Holmes, B. (2002). Proposed minimal standards for describing new taxa of the family Flavobacteriaceae and emended description of the family. Int J Syst Evol Microbiol 52, 1049-1070.

Chun, J., Lee, J.-H., Jung, Y., Kim, M., Kim, S., Kim, B. K. \& Lim, Y. W. (2007). EzTaxon: a web-based tool for the identification of prokaryotes based on $16 \mathrm{~S}$ ribosomal RNA gene sequences. Int J Syst Evol Microbiol 57, 2259-2261.

Collins, M. D., Pirouz, T., Goodfellow, M. \& Minnikin, D. E. (1977). Distribution of menaquinones in actinomycetes and corynebacteria. J Gen Microbiol 100, 221-230.

Doetsch, R. N. (1981). Determinative methods of light microscopy. In Manual of Methods for General Bacteriology, pp. 21-33. Edited by P. Gerhardt, R. G. E. Murray, R. N. Costilow, E. W. Nester, W. A. Wood, N. R. Krieg \& G. H. Phillips. Washington, DC: American Society for Microbiology.

Felsenstein, J. (1985). Confidence limits on phylogenies: an approach using the bootstrap. Evolution 39, 783-791.
Fitch, W. M. (1971). Toward defining the course of evolution: minimum change for a specific tree topology. Syst Zool 20, 406-416.

Kämpfer, P. \& Kroppenstedt, R. M. (1996). Numerical analysis of fatty acid patterns of coryneform bacteria and related taxa. Can J Microbiol 42, 989-1005.

Mesbah, M., Premachandran, U. \& Whitman, W. B. (1989). Precise measurement of the $\mathrm{G}+\mathrm{C}$ content of deoxyribonucleic acid by highperformance liquid chromatography. Int J Syst Bacteriol 39, 159-167.

Rainey, F. A., Ward-Rainey, N., Kroppenstedt, R. M. \& Stackebrandt, E. (1996). The genus Nocardiopsis represents a phylogenetically coherent taxon and a distinct actinomycete lineage: proposal of Nocardiopsiaceae fam. nov. Int J Syst Bacteriol 46, 1088-1092.

Reichenbach, H. (1992). The order Cytophagales. In The Prokaryotes, 2nd edn, vol. 4, pp. 3631-3675. Edited by A. Balows, H. G. Trüper, M. Dworkin, W. Harder \& K. H. Schleifer. New York: Springer.

Saitou, N. \& Nei, M. (1987). The neighbor-joining method: a new method for reconstructing phylogenetic trees. Mol Biol Evol 4, 406425.

Smibert, R. M. \& Krieg, N. R. (1994). Phenotypic characterization. In Methods for General and Molecular Bacteriology, pp. 607-654. Edited by P. Gerhardt, R. G. E. Murray, W. A. Wood \& N. R. Krieg. Washington, DC: American Society for Microbiology.

Stackebrandt, E. \& Goebel, B. M. (1994). Taxonomic note: a place for DNA-DNA reassociation and $16 \mathrm{~S}$ rRNA sequence analysis in the present species definition in bacteriology. Int J Syst Bacteriol 44, 846849.

Tamura, K., Dudley, J., Nei, M. \& Kumar, S. (2007). MEGA 4: Molecular evolutionary genetics analysis (MEGA) software version 4.0. Mol Biol Evol 24, 1596-1599.

Thompson, J. D., Gibson, T. J., Plewniak, F., Jeanmougin, F. \& Higgins, D. G. (1997). The CLUSTAL_X windows interface: flexible strategies for multiple sequence alignment aided by quality analysis tools. Nucleic Acids Res 25, 4876-4882.

Weon, H. Y., Kim, B. Y., Yoo, S. H., Lee, S. Y., Kwon, S. W., Go, S. J. \& Stackebrandt, E. (2006). Niastella koreensis gen. nov., sp. nov. and Niastella yeongjuensis sp. nov., novel members of the phylum Bacteroidetes, isolated from soil cultivated with Korean ginseng. Int J Syst Evol Microbiol 56, 1777-1782.

Wilson, K. (1987). Preparation of genomic DNA from bacteria. In Current Protocols in Molecular Biology, pp. 2.4.1-2.4.5. Edited by F. M. Ausubel, R. Brent, R. E. Kingston, D. D. Moore, J. G. Seidman, J. A. Smith \& K. Struhl. New York: Green Publishing \& Wiley-Interscience.

Xie, C. H. \& Yokota, A. (2003). Phylogenetic analysis of Lampropedia hyalina based on the 16S rRNA gene sequence. J Gen Appl Microbiol 49, 345-349.

Xie, C. H. \& Yokota, A. (2006). Reclassification of [Flavobacterium] ferrugineum as Terrimonas ferruginea gen. nov., comb. nov., and description of Terrimonas lutea sp. nov., isolated from soil. Int J Syst Evol Microbiol 56, 1117-1121.

Yoon, M. H. \& Im, W. T. (2007). Flavisolibacter ginsengiterrae gen. nov., sp. nov. and Flavisolibacter ginsengisoli sp. nov., isolated from ginseng cultivating soil. Int J Syst Evol Microbiol 57, 1834-1839. 